\title{
Analysis of Tax Compliance in Sub-Saharan Africa: Evidence from Firm-Level Study
}

\author{
Musa Abdu*, Adamu Jibir ${ }^{* \star}$, and Tasiu Muhammad ${ }^{\diamond}$ \\ PhD Student, Department of Economics \\ Ankara Yıldırım Beyazıt University, Turkey \\ -Department of Economics, Gombe State University, Nigeria \\ $\diamond^{\diamond}$ Postgraduate Fellow, Department of Economics \\ Ahmadu Bello University, Nigeria
}

Submitted: March 15, 2020 • Accepted: September 26, 2020

\begin{abstract}
This study analyses tax compliance among firms in Sub-Saharan Africa (SSA) within an extended Slippery Slope Framework (eSSF). It applies instrumental variables and generalized estimating equations models on a constructed World Bank's Enterprise Survey longitudinal dataset. The results indicate that the perceived power of the tax authorities does not influence firms' tax compliance, which could be linked to corruption in the form of informal payment. The results also show that corruption encourages the culture of tax non-compliance among firms in SSA because the defaulting firms bribe tax authorities in order to avoid paying taxes and being punished for that. In addition, the results demonstrate that the perceived trust of tax authorities (state representatives) is vitally important in encouraging tax compliance among firms in SSA. In terms of political decisions, it may be implied that gaining trust of taxpayers should be pursued.
\end{abstract}

JEL classification: DO3, H20, H24, H26, G41.

Keywords: Competition, Corruption, Power, Trust, Tax-compliance.

*Corresponding Author. E-mail: adamujibir@gmail.com 


\section{Introduction}

Over and above its revenue-generation role, taxation remains one of the most effective tools used to stabilise an economy and ensure equal redistribution of income. Nowadays, taxes are applied in the process of sanitising production of goods and services to guarantee health and overall wellbeing of people in the economy. In recent times, countries have struggled to levy large taxes in order to raise higher revenue and finance their ever-increasing demand for publicly produced goods and services. Tax-payers (including households and firms), however, perceive taxes as a burden. This negative attitude toward tax payments leads to tax evasion and tax avoidance which directly undermines the share of tax revenue $\mathrm{Alm}$, 2018; Antinyan et al., 2020). This trend has prompted some countries to introduce tax motivation packages such as improvement in government service delivery, trust and power in order to reduce the level of tax avoidance and improve the share of tax revenue (Gangl et al., 2020).

Even the classical economists had since accepted the government's intervention in the economy by collecting taxes with a view to providing public goods and services, ensuring security and enforcing law and order in the society. These investments, private sector in most cases, cannot make due to their large capital requirement and unprofitable nature. In connection to the role of tax collectors, governments all over the world enact various legislations to derive constitutional power to collect taxes from all actors in the economy (Varotsis and Katerelos, 2020).

Yet, tax non-compliance, in the form of tax avoidance and evasion, is still pervasive across both developed and developing countries despite tough penalties imposed on the culprits. There, naturally, is a group of actors who find it duty-bound to duly pay all their taxes without being coerced by the law (Slemrod, 2007), however, their number might decrease over time as they notice the fact that their counterparts successfully get away without punishment. Tax non-compliance is a great threat to any economy since it diminishes the capacity of the government to provide public goods and services. In addition, it makes fiscal policy instruments less effective in managing the macroeconomic environment.

Available statistics, related to the pervasive tax non-compliance, have shown that global economy loses a lot of tax revenue. IMF's researchers, Crivelli et al. (2016) estimated that the world's economies lose about US\$650 billion annually only to profit shifting as one of the ways of non-complying with tax payment. On the contrary, Cobham and Janský (2017) re-estimated the losses to be at US $\$ 500$ billion and observed that the intensity of losses is greatest in low- and lower-middle income countries.

Our study is motivated by the fact that while the extant literature dwells on the importance of tax revenue to economic growth and development (Lee and Gordon, 2005, Zeng et al., 2013, Crivelli et al., 2016, Babatunde et al., 2017), little effort has been made to examine the determinants of tax compliance among firms in SSA as mediated by corruption. In spite of the fact that corporate and business taxes largely contribute to a 
country's tax revenue (Muller and Kolk, 2015; Kleven et al., 2016), previous studies that focus on tax compliance mostly use individuals, countries and regions as their units of studies (Ayuba et al., 2018; Damayanti and Martono, 2018; Mardhiah et al., 2019; Gangl et al., 2020). Firm behavior is very different from individual behavior due to internal structure of industries which means that firms operate and make independent decisions (Alon and Hageman, 2013). The majority of studies that used firms as their units of analysis, are country-specific (Damayanti and Martono, 2018; Gberegbe and Umoren, 2017) and were conducted outside Sub-Saharan African countries therefore their findings may not be applicable to African countries (Alabede et al., 2011; Yee et al., 2017). So far very few studies attempted to integrate corruption as a mediating factor in testing the Slippery Slope Framework (SSF) in order to assess the determinants of tax compliance, which remains a critical task. According to Mardhiah et al. (2019), tax environment of most African countries is characterized by competing issues such as leakages, low level of public trust and high prevalence of corruption in tax administration and management which sharply contradicts what is obtainable in advanced countries where the SSF has been developed. Therefore, this study has been set out to fill this knowledge gap by testing the assumptions of the slippery slope framework with corruption as a mediating factor using firm level panel dataset for SSA.

This study makes several contributions in its own right. Firstly, it integrates tax compliance by firms and tax compliance in SSA. Similarly, by employing firm-level data obtained from the World Bank, it explores how variables proxying perceived power of authority and firms' trust in authority interact to determine the existence of tax compliance among firms in SSA. Essentially, the SSA region records poor and dwindling tax revenue as a percentage of GDP since it hovers between 13.18 and 15.94 for the period between 2010 and 2016 (World Bank, 2018b). Since African countries play an increasingly important role in the global economy, firms' tax compliance in the region is principally of interest to the rest of the world.

Secondly, to reflect the reality of SSA region in terms of how corruption is pronounced, the SSF is extended to incorporate corruption and country effects to provide findings about the mediating effect of corruption and other variables. African countries are mostly associated with high prevalence of corruption (Alon and Hageman, 2013). Thus, providing a deeper understanding of interplay between tax compliance and corruption remains an important task. Finally, from methodological point of view, this study addresses endogeneity and simultaneous bias, which usually transpire between firm tax compliance and corruption using both instrumental variable (IV) and generalized method of moments (GMM) techniques.

The paper is divided into five sections. The introduction is followed by the literature review which presents theoretical and empirical issues related to tax compliance. Section 3 presents the methodology of the study. It comprises data sources, model and tools of analysis. Section 4 provides the empirical analysis to substantiate the validity of eSSF. 
Section 5 summarizes the findings of the paper and provides interesting recommendations for policy prescription and direction.

\section{Literature Review and Development of Hypothesis}

\subsection{Theoretical Review}

From the theoretical point of view, the first standard economic model of tax compliance was developed by Allingham and Sandmo (1972), which was later revised by Srinivasan (1973) and Yitzhaki (1974). This model of tax compliance is based on Becker's analysis of criminal activities and the assumption that tax-payer's behaviour stands in line with the Von Neumann-Morgenstem axioms for behaviour under uncertainty. The model argues that the tax-payer's decision about whether or not to declare all their income for taxation depends on their income level that is exogenously determined, and the probability whether or not the authorities will investigate and establish their actual income. The model therefore posits that the decision is determined by the severity of penalty if the tax-payer is found guilty, and it is also a function of tax rate.

Interestingly, studies on tax-payer's behavior have significantly improved from relatively static neoclassical models to more dynamic and multidisciplinary ones, which now incorporate not only economic factors but also psychological and other social factors. The modern models are interdisciplinary in their quest to improve the analysis of taxpayers' behavior as regards compliance. Following this, Kirchler et al. (2008) formulated an economics- and psychology-based model of tax compliance, which is best known as Slippery Slope Framework (i.e. SSF) . They argued that the interaction between power of tax authorities and the trust in tax authorities determines the level of tax compliance given the relevant economic factors (Kirchler et al., 2008). The power of tax authorities here translates to the taxpayers'recognition for the ability of tax officers to detect the culprits of tax non-compliance and to punish them accordingly, through regular tax inspection and auditing. Hence, the resulting compliance from using power of authority is termed as enforced compliance.

SSF considers trust in tax authorities to be the overall view of the citizens and social groups that states are potent enough to use the tax proceeds to efficiently provide public goods and services for the general betterment of all in the society. Ensuring compliance via this channel is referred to as voluntary compliance (Kirchler et al., 2008). Kirchler, Hoelzl and Wahl therefore summarized that there were two types of taxpayers: honest and dishonest. While coercive measures are suitable for dishonest taxpayers, persuasive measures should be aimed at honest ones. At the same time authorities should cautiously use the two measures since excessive application of coercive measures could greatly erode trust and willingness to comply. This study applies SSF as its theoretical basis given its dynamic and interdisciplinary nature and ability to incorporate both economic and social 
factors in explaining the actual taxpayers' behavior towards tax compliance.

\subsection{Empirical Review}

\subsubsection{Power, Trust and Tax Compliance}

Given the enormous importance of taxation in modern economies, tax compliance has attracted a lot of studies to investigate reasons behind the prevailing tax non-compliance as one of the factors responsible for poor relative taxation revenue around the world. Studies on tax compliance among firms were reviewed below.

According to SSF, trust and power of authorities are the major factors determining tax compliance. Lisi (2014) used theoretical approach to analyze the model using firms. The study revealed that trust-building actions were better than deterring ones in making firms to comply with tax payments. Gangl et al. (2014) indirectly supported these findings by applying Probit and ordinary least squared regression models to experiment the effect of supervision on tax compliance in Austria. They concluded that supervision had no positive effect on tax compliance. On the contrary, it eroded intrinsic motivation of tax compliance among firms.

On the other hand, Naibei and Siringi (2011) discovered that effective and regular use of Electronic Tax Registers and business inspection had significant impact on the Value Added Tax (VAT) compliance among private business firms in Kisumu city in Kenya. This implies that coercive measures are effective in improving tax compliance. Similarly, using ordered probit regression model, Engida and Baisa (2014) found that firms' tax compliance was influenced by the probability of audit, financial constraints, and changes in government policy in Makkelle city in Ethiopia.

Rosid et al. (2017) found that different forms of perceived corruption can negatively influence individual tax-payer behavior. In the same vein, Gberegbe and Umoren (2017) established a positive influence of distributive fairness on personal income tax compliance. Furthermore, Ayuba et al. (2018), who tested the SSF model using Nigerian data set, discovered that perceived corruption and perceived service orientation strongly attract each other in expounding the paradox of tax compliance.

It has also been observed in the literature that the firms' scale of operation determines their probability to be tax compliant. For instance, Gauthier and Reinikka (2006) applied three-stage least square regression to investigate the impacts of tax reforms implemented in Uganda in the mid-1990s on the prevalence of tax evasion and exemptions among firms. Their findings suggest that tax exemptions are favorable to large firms, leading to more evasion among small businesses, and forcing medium-sized firms to shoulder a disproportionate tax burden. Almunia and Lopez-Rodriguez (2018) confirmed that a firm's size matters in determining tax compliance since certain firms tactically operate below the eligibility threshold in order to avoid stricter tax enforcement. Monitoring effort and the traceability of information reported by firms are complements in Spain. 
Alm et al. (2004) studied the criteria by which firms were selected for a sales tax audit and the determinants of subsequent firm compliance behavior, focusing on the Gross Receipts Tax in New Mexico. Using two-stage least square regression technique, the study established that firms displaying variation in deductions, provided services, miss-filing deadlines, and having an out-of-state mailing address, had a lower compliance rate. Hibbs and Piculescu (2010) in their panel study of 53 countries, using Panel Ordered Logit regression, found that institutional services, capital asset and tax toleration positively determine tax compliance while corporate tax rates negatively affects tax compliance. Sapiei et al. (2014) ascertained that business age, tax liability and tax complexity consistently influence the likelihood of tax non-compliance behavior among Malaysian firms.

Corruption has been identified as one of the major factors affecting firms' tax compliance especially in transition economies. Using also two-stage Least Square regression model and Business Environment and Enterprise Survey (BEEPS) for 23 transition European economies, Nur-Tegin (2008) analyzed the determinants of firms' tax compliance. The results showed that corruption had a negative and significant effect on firms' tax compliance. Similarly, Richter et al. (2009) confirmed that firms that spend more on lobbying (which is also a corruption) in a given year, paid lower effective tax rates in the next year. It was observed in their study of effect of lobbying on tax compliance among all U.S. firms with publicly available financial statements using also second-stage least square regression. Using both BEEP and Enterprise Survey data, studies by Joulfaian (2009) for transition economies and Alm et al. (2016) for 32 European countries with South Korea, also found that corruption negatively and significantly affected firms' tax compliance.

More so, Cai and Liu (2009) investigated whether or not market competition enhanced the incentives of Chinese industrial firms to avoid corporate income tax using Instrumental Variable. The study suggested that firms in more competitive environments more often engaged in tax avoidance activities. This could be in quest of maximizing profits by minimizing the cost of production.

In a recent study by Gangl et al. (2020), it has been revealed that the relationship between implicit trust and tax compliance was mediated by a confidence climate and committed cooperation. Mardhiah et al. (2019) found that trust leads to voluntary compliance and voluntary compliance, in turn, positively affects overall tax compliance. Yet, the study failed to find the evidence for the relationship between power and enforced compliance, although enforced compliance was found to negatively affect overall tax compliance. Similarly, Damayanti and Martono (2018), using multiple regression tests, concluded that trust and power both simultaneously and partially affect tax compliance. Based on the coefficient different tests, power had a greater impact than trust in creating tax compliance. This means that the compliance created in Indonesia is mandatory compliance that does not stem from self-assessment system that is based on voluntary compliance.

Antinyan et al. (2020) showed that a more trustworthy government exerts a positive effect on attitude toward tax payment. Martinez-Vazquez and Sanz-Arcega (2020) sup- 
ported this finding using Spanish data. Alm (2018) and Lisi (2019) demonstrated that voluntary tax compliance was more effective in promoting tax compliance than power used by tax authorities. On the other hand, Murphy (2019) found that tax non-compliance appeared to be high even in countries where citizens put trust in government.

It can be observed that the SSF recognizes the existence of interrelationship between taxpayers and authorities. The process through which this interaction occurs determines the level of compliance - through cooperation and application of power by authorities. Clearly, the majority of studies relate to the developed and emerging economies with relatively well-functioning tax administration and less corruption. Findings from these studies may not be applicable to developing countries with poorly functioning tax system and high prevalence of corruption. Therefore, further research is necessary in order to unravel the true picture of the situation for policy prescription and direction. It is within this premise that this paper tries to test the assumptions of SSF using firm-level data from SSA, which is assumed to be largely unexplored. To do this, we adopted the hypotheses of SSF developed by Kirchler and Wahl (2010) in the following way:

$\mathbf{H}_{1}$ : High taxpayer trust in government promotes voluntary tax compliance.

$\mathbf{H}_{2}$ : High perception of tax authorities' power by tax-payers leads to greater enforcement of tax compliance.

\subsubsection{Corruption and Tax Compliance}

Tax non-compliance and perception of corruption and bribery are generally agreed to be key challenges to state building in SSA countries. This, in recent times, has prompted academics, analysts and policy makers to identify strategies to improve tax compliance through deeper understanding of the nexus between tax compliance and corruption. Empirical studies examining factors contributing to corruption among firms found that firms were more inclined to bribery if their competitors were using such practices (Venaard, 2009; Alon and Hageman, 2013; Ufere et al., 2020). At the organizational level, firms use bribes to gain control and overcome bureaucracies in their business routines (Alon and Hageman, 2013; Ufere et al., 2020). Empirical studies on the effect of corruption on tax compliance are conducted worldwide. Alon and Hageman (2013), for instance, demonstrated that higher levels of corruption in tax administration causes low level of tax compliance. Similarly, Alm et al. (2016) indicated that larger bribes caused larger percentage of tax evasion. Amoh and Ali-Nakyea (2019), Rosid et al. (2019), Bertinelli et al. (2020), and Payne and Saunoris (2020) confirmed the significant negative effect of corruption and bribery on tax compliance among firms. While corruption and tax compliance has not been widely studied in Africa, there are few studies that concentrated their analysis on tax morale and motivations. Kamasa et al. (2019) reported that corruption by tax officials reduced the level of tax compliance. Jahnke and Weisser (2019) showed that petty corruption among firms in SSA eroded tax morale. 
Therefore, within the spirit of the above reviewed studies on the interrelationship between corruption/bribery and tax compliance/evasion, we expect to observe similar (negative) relationship between corruption/bribery and tax compliance/evasion among firm in SSA countries. Hence, we formulate our hypothesis as:

$\mathbf{H}_{3}$ : Prevalence of corruption negatively and significantly influence the level of tax compliance by firms.

The majority of findings, especially from the advanced countries show that trust is a vector of voluntary compliance, while power is a vector of enforced compliance, confirming the assumptions of the SSF. Therefore, this study aims to verify whether trust and power affect, respectively, enforced and voluntary tax compliance with corruption as a mediating factor. It also intends to compare the results obtained with the findings of studies from other countries. The results are expected not to fully comply with our established hypotheses - to demonstrate differences in institutional setting and trust in government between the developed countries and the SSA.

\section{Methodology and Data Sources}

\subsection{Theoretical Model of the Study and Variables' Measurement}

This study adapts slippery model of tax compliance given its advantage of incorporating non-economic factors in determining tax-payers' behaviour. As stated in the literature section, Kirchler et al. (2008) slippery model posits that tax is determined mainly by the tax payer's perception of power and trustworthy of authorities while controlling for the tax-payer, social norms and other economic factors. The functional-form of the model is specified as in equation (1):

$$
\operatorname{taxcm}_{i t}=f\left(\text { power }_{i t}, \text { trust }_{i t}, \text { econo }_{i t}, \text { socia }_{i t}, \text { insti }_{i t}\right)
$$

Where $\operatorname{taxcm}_{i t}$ is tax compliance; power $_{i t}$ is the perceived power of the authority; trust ${ }_{i t}$ is the perceived trustworthiness of the authority; econo $_{i t}$ is a vector of economic factors (tax-payer's income, tax, firm's size); socia $i t$ is a vector of social variables; and insti $_{i t}$ is a vector of institutional variables. The econometric form of the model was respecified as in equation (2):

$$
\operatorname{taxcm}_{i t}=\delta_{0}+\delta_{1} \text { power }_{i t}+\delta_{2} \text { trust }_{i t}+\delta_{3} \text { econo }_{i t}+\delta_{4} \text { Socia }_{i t}+\delta_{5} \text { insti }_{i t}+\mu_{i t}
$$

Where; $\delta_{i}$ stands for the parameters of the explanatory variables and $\mu_{i t}$ is the error term capturing other variables not included in the model. The apriori expectation of the model is: $\delta_{1}>0$ and $\delta_{2}>0$. Similar to Alm et al. (2016), in this study, tax compliance is measured in by the percentage of sales reported for tax. Perceived power of the authority 
is measured by the frequency of inspections by tax officials, tax rate and administration as obstacles to business. Perceived trustworthiness of the authority is measured by the percentage of electricity from generator(s) owned or shared by the firms and level of obstacle in obtaining business license, since these are the direct and most significant ways in which business enterprises benefit from states. Given the dearth of data and non-availability of other befitting variables, these variables are good proxies of infrastructure which have direct bearing on business operation, and state is supposed to provide these infrastructures using tax and non-tax revenue. A vector of economic variables includes tax-payer's income, firm's size and ownership structure. A vector of social variables includes informal payment as a percentage of sales and bribe to tax collectors. A vector of institutional variables includes the level of fairness and incorruptness of court(s) in such countries and legal status of the firms (shareholding, sole-proprietorship and partnership).

\subsection{Data and Estimation Techniques}

This study used the World Bank's (2018a) Enterprise Survey data to meet its objectives. Enterprise Survey is a nationally representative dataset obtained randomly from various business establishments across the country, involved mainly in manufacturing, retail and other services. The Enterprise Surveys center around the several factors that shape the business environment. These factors are either constraining firms' performance or are viewed as sine qua non for firms' prosperity.

Given the fact that our study seeks to extend Slippery Slope Framework and the variables to be included in the model are bribery and corruption, among other relevant firms' characteristics; there might be a problem of endogeneity. As argued by Cule and Fulton (2000) and Alm et al. (2016), bribery and tax evasion are likely to covariate at firm level as corruption encourages firms to evade paying tax especially when amount of bribery and corruption is lower than the amount of tax payment evaded. This is particularly pronounced in Sub-Saharan Africa given the high pervasiveness of corruption in the region. To address this endogeneity problem, we use instrumental variables (IV) approach, which is designed to resolve the challenges of omitted variables, simultaneity measurement error in the regressors, and sample selection bias. Instrumental variables method belongs to the family of generalized method of moments (GMM) framework since a surplus of instruments leads to an excess of moment conditions that can be used for estimation (Cameron and Trivedi, 2005). Given that the dependent (percentage of sales of reported for tax purposes) appears to be truncated from both left (0) and from right (1), instrumental variable Tobit model is being estimated. To estimate IV Tobit model, we have selected suitable instruments, which are variables that correlate with endogeneous variables (bribery and corruption) but are not correlated with dependent variable (tax evasion). As in Alm et al. (2016), we selected bribery to get connected to infrastructure (electricity, water and communication), in order to obtain business license and to get contract. Since the number of instruments is greater than that of endogeneous variables, 
the equation is over-identified.

For robustness check, we also estimated the panel version of generalized linear model (GLM) that is generalized estimating equations (GEE). The term generalized linear model (GLIM or GLM) refers to a larger class of models in which the response variable is assumed to follow an exponential family distribution with mean $\mu_{i t}$, which is assumed to be some (often nonlinear) function of $x_{i t}^{T} \beta$. Some would call these "nonlinear" because $\mu_{i t}$ is often a nonlinear function of the covariates, but we consider them to be linear, because the covariates affect the distribution of $y_{i t}$ only through the linear combination $x_{i t}^{T} \beta$ (McCullagh and Nelder, 1989). Thus, binomial logit version of GEE is used because we converted percentage of sales reported for tax purposes into decimal number by dividing it by 100 .

\section{Presentation and Discussion of Results}

Table 1 shows the descriptions and measurements of all variables in the tax compliance models. The variables are measured in line with econometric principles and previous relevant studies.

At the bottom of Table 1, 42 countries and the year surveys from the period between 2003 and 2018 are presented. These countries and survey years are considered representative of Sub-Saharan Africa since they include many countries from all parts of SSA.

Table 2 presents the summary statistics of all variables in the tax compliance models where firm's size and sales are continuous variables in natural logarithmic form; electricity from generator, domestic private and foreign ownerships, contract bribe, sales percentage and sales bribe are in percentage units of measurement. The remaining variables are discrete choice ones (dummies). Table 3 describes the distribution of mean values of sales reported for tax purposes, frequency of tax inspection, electricity from generator and bribery as a proportion of sales by scales of operation and regions. Table 3 clearly shows that the scale of operation is correlated with the tax compliance where large-scale firms reported on average more proportion of sales for tax purposes (68.50 percent) than other firms. This is immediately followed by medium-scale enterprises (65.86 percent) and small-scale firms are last (61.35 percent). This could be the result of frequency of tax inspection as large-scale firms were on average (4.04 times) more frequently inspected than other firms.

Table 3 also indicates that large-scale firms enjoyed public goods and services the most as they generated on average the least electricity from their generators (26.83 percent) in comparison to other firms. The table depicts that large-scale firms have the lowest incidence of sales bribe while small-scale firms have the highest incidence of sales bribe. Table 3 shows that the mean value of sales reported for tax purposes in which Eastern Africa records the highest percentage (62.60) followed by Western Africa with 61.54 percent though the two regions have the highest proportion of electricity from generators of 
Table 1: Descriptions and Measurement of the Variables

\begin{tabular}{|c|c|}
\hline Variables & Descriptions \\
\hline Sales Percentage & Percentage of Sales Reported for Tax Purposes \\
\hline Sales indices & Percentage of Sales Reported for Tax Purposes divided by 100 \\
\hline Tax rate obstacle & $\begin{array}{l}\text { Tax rate as an obstacle to business ( } 0 \text { for no obstacle, } 1 \text { for minor, } 2 \text { for } \\
\text { moderate, } 3 \text { for severe and } 4 \text { for very severe obstacle) }\end{array}$ \\
\hline Tax admin. obstacle & $\begin{array}{l}\text { Tax regulations as an obstacle to business ( } 0 \text { for no obstacle, } 1 \text { for minor, } \\
2 \text { for moderate, } 3 \text { for severe and } 4 \text { for very severe obstacle) }\end{array}$ \\
\hline Tax inspection freq. & Number of times a firm was inspected by Tax authorities in a year \\
\hline Biz license obstacle & $\begin{array}{l}\text { Obtaining business license as an obstacle to business ( } 0 \text { for no obstacle, } 1 \text { for } \\
\text { minor, } 2 \text { for moderate, } 3 \text { for severe and } 4 \text { for very severe obstacle) }\end{array}$ \\
\hline Generator electricity & Percentage of electricity obtained from generator(s) owned or shared by a firm \\
\hline Tax bribe & Binary dummy for bribe requested by Tax officials ( 1 for Yes and 0 for No) \\
\hline Sales bribe & Informal payment (bribery) as a percentage of total sales \\
\hline Uncorrupt judiciary & $\begin{array}{l}\text { Perception of court system as fair, impartial and uncorrupted ( } 1 \text { for strongly } \\
\text { disagreed, } 2 \text { for disagreed, } 3 \text { for agreed and } 4 \text { for strong agreed) }\end{array}$ \\
\hline Sales $(\log )$ & Natural logarithm of total sales in the last fiscal year. \\
\hline Firm size & Logarithm of permanent and full-time employees of a firm \\
\hline Sole proprietorship & Dummy for a firm registered as a sole proprietorship \\
\hline Partnership & Dummy for a firm registered as a partnership \\
\hline Private ownership & Percentage of a firm owned by private individuals \\
\hline Foreign ownership & Percentage of a firm owned by foreign investors \\
\hline Contract bribe & $\begin{array}{l}\text { Percentage of contract value paid as informal gifts to secure government } \\
\text { contract }\end{array}$ \\
\hline Business bribe & $\begin{array}{l}\text { Binary dummy for bribe requested to obtain business license ( } 1 \text { for Yes and } \\
0 \text { for No) }\end{array}$ \\
\hline Infrastructure bribe & $\begin{array}{l}\text { Binary dummy for bribe requested to get connected to infrastructure ( } 1 \text { for } \\
\text { Yes and } 0 \text { for No) }\end{array}$ \\
\hline \multicolumn{2}{|c|}{$\begin{array}{l}\text { Angola (2006 \& 2010), Benin (2004, } 2009 \& \text { 2016), Botswana (2006 \& 2010), } \\
\text { Burkina Faso (2006 \& 2009), Burundi (2014), Cameroon (2006, } 2009 \& 2016), \\
\text { Cape Verde (2006 \& 2009), Central African Republic (2011), Chad (2018), Congo Republic (2009 } \\
\text { Côted' Ivoire (2009 \& 2016), Democratic Republic of Congo (2010 \& 2013), Eritrea (2009), } \\
\text { Eswatini (2016), Ethiopia (2011), Gabon (2009), Gambia (2018), Ghana (2007 \& 2013), } \\
\text { Guinea (2016), Kenya (2007 \& 2013), Lesotho (2009 \& 2016), Liberia (2009 \& 2017), } \\
\text { Madagascar (2013), Malawi (2009 \& 2014), Mali (2003, 2007, } 2010 \& 2016) \text {, Mauritania (2014), } \\
\text { Mauritius (2009), Mozambique (2007), Namibia (2014), Niger (2005, } 2009 \& 2017), \\
\text { Rwanda (2006 \& 2011), Senegal (2007 \& 2014), Sierra Leone (2009 \& 2017), } \\
\text { South Africa (2003 \& 2007), South Sudan (2014), Sudan (2014), Tanzania (2006 \& 2013), } \\
\text { Togo (2009 \& 2016), Uganda (2006 \& 2013) and Zambia (2007 \& 2013) }\end{array}$} \\
\hline
\end{tabular}

Source: Authors' construction using World Bank's Enterprise Survey Data

38.88 and 41.00 percent respectively. More so, firms in Eastern and Western Africa were inspected more often (about 3.8) than any other region.

Table 4 reports results of pair-wise correlation among the bribery variables and shows that the potential instruments have weak correlation with percentage sales reported for tax purposes. It also indicates that the potential instruments (contract bribe, license bribe and infrastructure bribe) have relatively strong correlation with sales bribe, especially contract bribe with about 47 percent.

In addition, data in Table 4 suggest that the instruments have also relatively strong correlation with tax bribe, particularly license bribe and infrastructure bribe with about 
Table 2: Summary Statistics of Variables in the Models

\begin{tabular}{lccclc}
\hline Variables & Observation & Mean & Standard Dev. & Minimum & Maximum \\
\hline Sales Percentage & 32,371 & 61.49611 & 15.62247 & 0 & 100 \\
Sales indices & 32,371 & 0.6149611 & 0.1562247 & 0 & 1 \\
Tax rate obstacle & 31,761 & 1.829445 & 1.301267 & 0 & 4 \\
Tax admin. obstacle & 31,786 & 1.568049 & 1.282367 & 0 & 4 \\
Tax inspection freq. & 32,371 & 3.828912 & 4.641477 & 0 & 100 \\
Biz license obstacle & 23,326 & 1.208737 & 1.217251 & 0 & 4 \\
Electric Generator & 32,371 & 39.08021 & 22.08252 & 0 & 100 \\
Tax bribe & 32,371 & 0.1927905 & 0.3278921 & 0 & 1 \\
Sales bribe & 32,371 & 2.323167 & 6.168145 & 0 & 100 \\
Uncorrupt judicial & 32,371 & 2.396418 & 0.9327302 & 1 & 4 \\
Lnsales & 28,689 & 16.6839 & 2.983859 & 1.94591 & 34.10491 \\
Firm's size & 31,939 & 2.71572 & 1.223864 & 0 & 11.06664 \\
Firm's age & 26,361 & 15.51125 & 13.98298 & 0 & 172 \\
Sole proprietorship & 32,371 & 0.5814464 & 0.4933295 & 0 & 1 \\
Partnership & 32,371 & 0.173674 & 0.3788347 & 0 & 1 \\
Domestic Priv. own & 31,835 & 82.96621 & 35.17144 & 0 & 100 \\
Foreign ownership & 31,809 & 10.79347 & 28.68822 & 0 & 100 \\
Contract bribe & 32,371 & 4.902999 & 5.535908 & 0 & 100 \\
Business bribe & 32,371 & 0.1989566 & 0.2073267 & 0 & 1 \\
Infrastructure bribe & 32,371 & 0.3525272 & 0.234672 & 0 & 1 \\
\hline
\end{tabular}

Source: Authors' construction using World Bank's Enterprise Survey Data

48 and 41 percent respectively. Thus, this correlation has shown that the instruments have met the first condition that they should correlate with bribery but should not correlate with sales percentage.

To test for the second condition, first stage Tobit and Probit models on the effects of the instruments on sales bribe and tax bribe were estimated and the results are presented in Table 5. It shows that contract bribe, business licence bribe and infrastructure are significantly and positively determining the informal payment as a proportion of sales (sales bribery) and bribe requested during tax collection.

They are all significant at 1 percent level. Other significant variables include tax rate obstacle, tax regulation obstacle, tax inspection frequency, business license obstacle, electricity from generators, sales, size, age, legal status, ownership structure and uncorrupt judicial system.

Therefore, results from the first stage models have confirmed that the instruments meet the second condition i.e. they are significant in determining the instrumented variables.

Table 6 presents results of the estimated linear dummy variable (unconditioned fixedeffect Tobit), unconditional fixed-effect Tobit ${ }^{1}$, two-staged least squared (2SLS) and generalized method of moments (GMM) instrumental variables (IV) models. First Tobit model in Table 6 is a baseline model without briberies and the model suggests that tax

\footnotetext{
${ }^{1}$ An unconditional fixed effect Tobit regression model is estimated given absence of formal approach of estimating the conditional one. Like Zambrano (2005), we fitted the fixed effect Tobit model by estimating linear Tobit with Time variant, industrial and country effect. However, this estimation does not also give room for estimating Hausman test.
} 
Table 3: Distribution of Some Tax Compliance Variables

\begin{tabular}{|c|c|c|c|c|c|}
\hline & Observations & $\begin{array}{c}\text { Sales } \\
\text { Reported for } \\
\text { Tax Purposes }\end{array}$ & $\begin{array}{c}\text { Frequency } \\
\text { of Tax } \\
\text { Inspection }\end{array}$ & $\begin{array}{l}\text { Electricity } \\
\text { from } \\
\text { Generator }\end{array}$ & $\begin{array}{c}\text { Bribery as } \\
\text { a Proportion } \\
\text { of Sales }\end{array}$ \\
\hline \multicolumn{6}{|c|}{ By Scales of Operation } \\
\hline Micro & 13,864 & $\begin{array}{l}59.6503^{* * *} \\
(0.12439)\end{array}$ & $\begin{array}{l}3.830919^{* * *} \\
(0.03973)\end{array}$ & $\begin{array}{l}42.3061^{* * *} \\
(0.17198)\end{array}$ & $\begin{array}{c}2.3073^{* * *} \\
(0.05222)\end{array}$ \\
\hline Small & 13,084 & $\begin{array}{l}61.3522^{* * *} \\
(0.14171)\end{array}$ & $\begin{array}{c}3.8309^{* * *} \\
(0.03909)\end{array}$ & $\begin{array}{l}39.1424^{* * *} \\
(0.19547)\end{array}$ & $\begin{array}{c}2.5542^{* * *} \\
(0.05781)\end{array}$ \\
\hline Medium & 3,972 & $\begin{array}{l}65.8566^{* * *} \\
(0.25457)\end{array}$ & $\begin{array}{c}3.7361^{* * *} \\
(0.07285)\end{array}$ & $\begin{array}{l}32.0898^{* * *} \\
(0.37136)\end{array}$ & $\begin{array}{c}1.9561^{* * *} \\
(0.08427)\end{array}$ \\
\hline Large & 1,451 & $\begin{array}{l}68.4939 * * * \\
(0.35983)\end{array}$ & $\begin{array}{c}4.0458^{* * *} \\
(0.15194)\end{array}$ & $\begin{array}{l}26.8324^{* * *} \\
(0.62758)\end{array}$ & $\begin{array}{l}1.3970^{* * *} \\
(0.09949)\end{array}$ \\
\hline \multicolumn{6}{|c|}{ By Regions } \\
\hline Central Africa & 3,237 & $\begin{array}{l}60.0789^{* * *} \\
(0.50981)\end{array}$ & $\begin{array}{l}3.589521^{* * *} \\
(0.08677)\end{array}$ & $\begin{array}{l}28.9185^{* * * *} \\
(0.33212)\end{array}$ & $\begin{array}{l}1.867024^{* * *} \\
(0.10226)\end{array}$ \\
\hline Eastern Africa & 5,921 & $\begin{array}{l}62.60156^{* * *} \\
(0.193279)\end{array}$ & $\begin{array}{l}3.889929^{* * *} \\
(0.06719)\end{array}$ & $\begin{array}{l}38.87709^{* * *} \\
(0.23708)\end{array}$ & $\begin{array}{l}2.215908^{* * *} \\
(0.06932)\end{array}$ \\
\hline Southern Africa & 2,274 & $\begin{array}{l}60.2021^{* * *} \\
(0.40335)\end{array}$ & $\begin{array}{c}3.6801^{* * *} \\
(0.08574)\end{array}$ & $\begin{array}{l}36.3665^{* * *} \\
(0.44686)\end{array}$ & $\begin{array}{l}2.88767^{* * *} \\
(0.15891)\end{array}$ \\
\hline Western Africa & 20,939 & $\begin{array}{l}61.5432^{* * *} \\
(0.08286)\end{array}$ & $\begin{array}{l}3.86483^{* * *} \\
(0.03102)\end{array}$ & $\begin{array}{l}41.0033^{* * *} \\
(0.15982)\end{array}$ & $\begin{array}{l}2.36271^{* * *} \\
(0.04329)\end{array}$ \\
\hline Full Sample & 32,371 & $\begin{array}{l}61.4961^{* * *} \\
(0.08683)\end{array}$ & $\begin{array}{l}3.8289 * * * \\
(0.02580)\end{array}$ & $\begin{array}{l}39.0802^{* * *} \\
(0.12274)\end{array}$ & $\begin{array}{l}2.32317^{* * *} \\
(0.03428)\end{array}$ \\
\hline
\end{tabular}

Standard error in parentheses, Source: Authors' construction using World Bank's Enterprise Survey Data

Table 4: Pair-Wise Correlation of Bribery Variables for Selection of Instruments

\begin{tabular}{clrcccccc}
\hline $\mathbf{S} / \mathbf{N}$ & Variables & $\mathbf{1}$ & $\mathbf{2}$ & $\mathbf{3}$ & $\mathbf{4}$ & $\mathbf{5}$ & $\mathbf{6}$ & $\mathbf{7}$ \\
\hline 1 & Sales percentage & 1.0000 & & & & & & \\
2 & Sales bribe & -0.1245 & 1.0000 & & & & & \\
3 & Tax Bribe & -0.1229 & 0.2032 & 1.0000 & & & & \\
4 & Contract bribe & -0.1205 & 0.4713 & 0.2166 & 1.0000 & & & \\
5 & License bribe & -0.1199 & 0.2373 & 0.4877 & 0.3016 & 1.0000 & & \\
6 & Infrastructure bribe & -0.0817 & 0.1676 & 0.4083 & 0.2048 & 0.5637 & 1.0000 & \\
7 & Time on Regulation & 0.0464 & 0.1344 & 0.0302 & 0.0541 & 0.0652 & 0.0025 & 1.0000 \\
\hline
\end{tabular}

Source: Authors' construction using World Bank's Enterprise Survey Data

rate and tax regulation as obstacles to business are significant at 1 percent in determining the proportion of sales reported for tax purposes.

Contrary to theoretical expectations, they are positively significant. This is plausible since the complication of tax rate and tax regulation could be in favour of the firms, which, in turn, may be encouraged to direct more of the sales for tax purposes. The model further reveals that the frequency of tax inspection forces the firms to report high 
Table 5: First Stage Tobit and Probit Models on the Effects of Instruments

\begin{tabular}{|c|c|c|}
\hline Variables & $\begin{array}{c}\text { Tobit } \\
\text { Sales Bribery }\end{array}$ & $\begin{array}{c}\text { Probit Model } \\
\text { Tax Bribery }\end{array}$ \\
\hline Contract bribe & $\begin{array}{c}0.00534^{* * *} \\
(0.000376)\end{array}$ & $\begin{array}{c}0.0121^{* * *} \\
(0.00242)\end{array}$ \\
\hline License bribe & $\begin{array}{l}0.0567 * * * \\
(0.00586)\end{array}$ & $\begin{array}{l}0.793^{* * *} \\
(0.0608)\end{array}$ \\
\hline Infrastructure score & $\begin{array}{l}0.0350 * * * \\
(0.00564)\end{array}$ & $\begin{array}{l}0.568^{* * *} \\
(0.0559)\end{array}$ \\
\hline Tax rate obst. & $\begin{array}{c}0.000936 \\
(0.000962)\end{array}$ & $\begin{array}{c}-0.0679^{* * *} \\
(0.0104)\end{array}$ \\
\hline Tax admin. Obst. & $\begin{array}{c}0.00491^{* * *} \\
(0.00104)\end{array}$ & $\begin{array}{l}0.0236^{* *} \\
(0.0112)\end{array}$ \\
\hline Tax inspection freq. & $\begin{array}{c}0.00127 * * * \\
(0.000167)\end{array}$ & $\begin{array}{l}0.0246^{* * *} \\
(0.00326)\end{array}$ \\
\hline Business license obstacle & $\begin{array}{c}0.00343^{* * *} \\
(0.000945)\end{array}$ & $\begin{array}{l}0.0215^{* *} \\
(0.00984)\end{array}$ \\
\hline Electric generator & $\begin{array}{c}0.000201^{* * *} \\
(6.46 \mathrm{e}-05)\end{array}$ & $\begin{array}{l}-0.000277 \\
(0.000611)\end{array}$ \\
\hline Sales $(\log )$ & $\begin{array}{c}-0.000961^{* *} \\
(0.000389)\end{array}$ & $\begin{array}{c}-0.0126^{* * *} \\
(0.00405)\end{array}$ \\
\hline Firm's size & $\begin{array}{c}-0.00420^{* * *} \\
(0.000959)\end{array}$ & $\begin{array}{c}-0.102^{* * *} \\
(0.0105)\end{array}$ \\
\hline Firm's age & $\begin{array}{c}1.07 \mathrm{e}-05^{* * *} \\
(3.98 \mathrm{e}-06)\end{array}$ & $\begin{array}{l}9.25 \mathrm{e}-05^{* *} \\
(3.73 \mathrm{e}-05)\end{array}$ \\
\hline Uncorrupt judiciary & $\begin{array}{c}-0.00620^{* * *} \\
(0.00120)\end{array}$ & $\begin{array}{c}-0.0571^{* * *} \\
(0.0117)\end{array}$ \\
\hline Sole proprietorship & $\begin{array}{c}-0.00627^{* *} \\
(0.00274)\end{array}$ & $\begin{array}{c}-0.185^{* * *} \\
(0.0292)\end{array}$ \\
\hline Partnership & $\begin{array}{c}0.00241 \\
(0.00304)\end{array}$ & $\begin{array}{c}-0.0852^{* * *} \\
(0.0329)\end{array}$ \\
\hline privateown & $\begin{array}{c}-0.000193^{* * *} \\
(5.01 \mathrm{e}-05)\end{array}$ & $\begin{array}{l}-0.000753 \\
(0.000493)\end{array}$ \\
\hline foreignown & $\begin{array}{c}-0.000195^{* * *} \\
(5.71 \mathrm{e}-05)\end{array}$ & $\begin{array}{l}-0.000880 \\
(0.000588)\end{array}$ \\
\hline Constant & $\begin{array}{c}-0.00382 \\
(0.0119)\end{array}$ & $\begin{array}{c}0.693^{* * *} \\
(0.153)\end{array}$ \\
\hline Year effect & Yes & Yes \\
\hline Industrial effect & Yes & Yes \\
\hline Country Effect & Yes & Yes \\
\hline Observations & 15,885 & 15,885 \\
\hline
\end{tabular}

Robust standard errors in parentheses ${ }^{* * *} p<0.01,{ }^{* *} p<0.05$, and ${ }^{*} p<0.1$

proportion of their sales for tax purposes as the inspection makes it easier for the tax authorities to detect the defaulters, thereby taking legal actions against the defaulters. This means that the perception of the power of tax authorities matters a lot in enforcing tax compliance among firms.

Business license as an obstacle to business and proportion of electricity firm's generators are negatively significant in influencing tax compliance among firms in the region. This implies that the perception of trustworthiness of tax authorities, as measured by the 
authorities' commitments to friendly business environment, motivates the firms to comply with tax payment. Models 2, 3 and 4 in Table 6 are instrumental variables of different versions, which were estimated to resolve the endogeneity problem of sales and tax bribery in tax-compliance model. They are consistent in reporting the same variables that are significant at the same levels and with same signs though with slight differences in sizes. The models show that sales bribe is negatively and significantly associated with proportion of sales reported for tax purposes. By including the bribery and other controlled variables in the models, tax inspection frequency in the models becomes insignificant, which indicates that bribery undermines perceived power of the tax authorities to enforce tax compliance among firms. The instrumental variable models in Table 6 also reveal that business license as an obstacle to business is still negatively significant, yet proportion of electricity from generator is negatively insignificant.

By this finding, it means the perceived trust in tax authorities is still important in motivating the firms to be highly tax-compliant. Other important findings of the IV models include uncorrupt, impartial and just judiciary system, firms'size, being sole proprietor and domestic privately owned firms. It is clear that judiciary institution is important in controlling bribery and encouraging tax compliance as shown in Table 5. This is not farfetched since firms would probably not be willing to take chances to be tax non-compliant as mere whistle blowing may expose them and judiciary would not hesitate to prosecute them accordingly. Again, firm's size is positively significant in affecting tax compliance. This may be due to the fact that large firms are usually well-established and do not want to risk their image being tarnished and prevent them from making a lot of profits. This further motivates them to be tax compliant.

This finding is also corroborated by the negative significant of sole proprietorship, which is a form of business venture which is usually micro or small in sizes or scale. Crucially, the tests of over-identification for both 2SLS and GMM show that the models are over-identified while endogeneity tests reject the null hypothesis that all the variables are exogenous.

For robustness check and further verification of how consistent the findings of IV model are, generalized estimating equations were estimated and results presented in Table 7 . The table shows that trust in authorities is what matters to firms when paying taxes. Model 1 in Table 7 has confirmed the finding (of first Tobit model in Table 6) that tax rate and business license as obstacles to business are significant in determining tax compliance among firms in SSA. Model 3 of Table 7 has properly, albeit with marginal differences in sizes, corroborated the findings of the IV models in Table 6 that sales bribe, tax rate and business license as obstacles to business are fundamentals to enforcing tax compliance among firms in SSA. However, uncorrupt judiciary is found to be positively insignificant in Model 3 of Table 7. Moreover, firm's size, sole proprietorship and domestic private ownership are all significant with same signs as in IV models in Table 6.

The trust in authorities (representatives of state) matters given the negative signifi- 
Table 6: Determinants of Tax Compliance in Sub-Saharan Africa

\begin{tabular}{|c|c|c|c|c|}
\hline Tax Sales Percentage & $\begin{array}{c}(1) \\
\text { Tobit }\end{array}$ & $\begin{array}{c}(2) \\
\text { Tobit-IV }\end{array}$ & $\begin{array}{c}(3) \\
\text { 2SLS-IV }\end{array}$ & $\begin{array}{c}(4) \\
\text { GMM-IV }\end{array}$ \\
\hline Sales bribe & & $\begin{array}{c}-0.0058^{* * *} \\
(0.0013)\end{array}$ & $\begin{array}{c}-0.00479^{* * *} \\
(0.00119)\end{array}$ & $\begin{array}{c}-0.00477^{* * *} \\
(0.00118)\end{array}$ \\
\hline Tax bribe & & $\begin{array}{l}-0.0092 \\
(0.0270)\end{array}$ & $\begin{array}{c}-0.00943 \\
(0.0240)\end{array}$ & $\begin{array}{c}-0.00976 \\
(0.0240)\end{array}$ \\
\hline Tax rate obstacle & $\begin{array}{c}0.00530^{* * *} \\
(0.000931)\end{array}$ & $\begin{array}{c}0.0049 * * * \\
(0.0016)\end{array}$ & $\begin{array}{c}0.00516^{* * *} \\
(0.00139)\end{array}$ & $\begin{array}{c}0.00509 * * * \\
(0.00139)\end{array}$ \\
\hline Tax reg. obstacle & $\begin{array}{c}0.00386^{* * *} \\
(0.000949)\end{array}$ & $\begin{array}{l}0.00034 \\
(0.0017)\end{array}$ & $\begin{array}{l}0.000472 \\
(0.00155)\end{array}$ & $\begin{array}{l}0.000639 \\
(0.00155)\end{array}$ \\
\hline Tax inspection freq. & $\begin{array}{l}0.000299^{*} \\
(0.000163)\end{array}$ & $\begin{array}{c}0.00028 \\
(0.00033)\end{array}$ & $\begin{array}{l}0.000283 \\
(0.000295)\end{array}$ & $\begin{array}{c}0.000284 \\
(0.000295)\end{array}$ \\
\hline Biz license obstacle & $\begin{array}{c}-0.00431^{* * *} \\
(0.000976)\end{array}$ & $\begin{array}{c}-0.0070^{* * *} \\
(0.0016)\end{array}$ & $\begin{array}{c}-0.00632^{* * *} \\
(0.00147)\end{array}$ & $\begin{array}{c}-0.00646^{* * *} \\
(0.00147)\end{array}$ \\
\hline Electricity from gen & $\begin{array}{c}-0.000139^{* * *} \\
(4.87 \mathrm{e}-05)\end{array}$ & $\begin{array}{l}-0.00003 \\
(0.00008)\end{array}$ & $\begin{array}{l}-3.93 \mathrm{e}-05 \\
(6.95 \mathrm{e}-05)\end{array}$ & $\begin{array}{l}-4.08 \mathrm{e}-05 \\
(6.95 \mathrm{e}-05)\end{array}$ \\
\hline Sales (log) & $\begin{array}{c}0.00359 * * * \\
(0.000377)\end{array}$ & $\begin{array}{c}4.98 \mathrm{e}-06 \\
(0.00059)\end{array}$ & $\begin{array}{c}0.000531 \\
(0.000524)\end{array}$ & $\begin{array}{c}0.000555 \\
(0.000524)\end{array}$ \\
\hline Firm's Size & $\begin{array}{c}2.00 \mathrm{e}-05 \\
(0.000947)\end{array}$ & $\begin{array}{c}0.0113^{* * *} \\
(0.0016)\end{array}$ & $\begin{array}{c}0.00942^{* * *} \\
(0.00137)\end{array}$ & $\begin{array}{c}0.00938^{* * *} \\
(0.00137)\end{array}$ \\
\hline Age & $\begin{array}{l}2.70 \mathrm{e}-07 \\
(2.93 \mathrm{e}-06)\end{array}$ & $\begin{array}{c}-1.14 \mathrm{e}-06 \\
(4.43 \mathrm{e}-06)\end{array}$ & $\begin{array}{l}-1.11 \mathrm{e}-06 \\
(4.02 \mathrm{e}-06)\end{array}$ & $\begin{array}{l}-1.29 \mathrm{e}-06 \\
(4.02 \mathrm{e}-06)\end{array}$ \\
\hline Sole proprietorship & $\begin{array}{c}-0.0781^{* * *} \\
(0.00331)\end{array}$ & $\begin{array}{c}-0.1004^{* * *} \\
(0.00483)\end{array}$ & $\begin{array}{c}-0.0932^{* * *} \\
(0.00432)\end{array}$ & $\begin{array}{c}-0.0935^{* * *} \\
(0.00432)\end{array}$ \\
\hline Partnership & $\begin{array}{c}-0.00605^{*} \\
(0.00353)\end{array}$ & $\begin{array}{l}-0.0066 \\
(0.0056)\end{array}$ & $\begin{array}{l}-0.00462 \\
(0.00492)\end{array}$ & $\begin{array}{l}-0.00491 \\
(0.00492)\end{array}$ \\
\hline Private ownership & $\begin{array}{l}3.64 \mathrm{e}-05 \\
(3.98 \mathrm{e}-05)\end{array}$ & $\begin{array}{c}0.00016^{* * *} \\
(0.00006)\end{array}$ & $\begin{array}{c}0.000134^{* *} \\
(5.48 \mathrm{e}-05)\end{array}$ & $\begin{array}{c}0.000136^{* *} \\
(5.48 \mathrm{e}-05)\end{array}$ \\
\hline Foreign ownership & $\begin{array}{l}-3.92 \mathrm{e}-05 \\
(5.50 \mathrm{e}-05)\end{array}$ & $\begin{array}{c}0.00007 \\
(0.00008)\end{array}$ & $\begin{array}{c}6.41 \mathrm{e}-05 \\
(7.58 \mathrm{e}-05)\end{array}$ & $\begin{array}{c}6.57 \mathrm{e}-05 \\
(7.58 \mathrm{e}-05)\end{array}$ \\
\hline Uncorrupt judicial & & $\begin{array}{c}0.0051^{* * *} \\
(0.0019)\end{array}$ & $\begin{array}{c}0.00384^{* *} \\
(0.00174)\end{array}$ & $\begin{array}{r}0.00373^{* *} \\
(0.00174)\end{array}$ \\
\hline Constant & $\begin{array}{l}0.5760^{* * *} \\
(0.00917)\end{array}$ & $\begin{array}{c}0.6459^{* * *} \\
(0.0156)\end{array}$ & $\begin{array}{c}60.18^{* * *} \\
(1.178)\end{array}$ & $\begin{array}{c}60.19^{* * *} \\
(1.151)\end{array}$ \\
\hline $\begin{array}{l}\text { Year effect } \\
\text { Industrial effect } \\
\text { Country Effect }\end{array}$ & & $\begin{array}{l}\text { Yes } \\
\text { Yes } \\
\text { Yes }\end{array}$ & $\begin{array}{l}\text { Yes } \\
\text { Yes } \\
\text { Yes }\end{array}$ & $\begin{array}{l}\text { Yes } \\
\text { Yes } \\
\text { Yes }\end{array}$ \\
\hline Observations & 14,181 & 15,885 & 15,885 & 15,885 \\
\hline \multicolumn{5}{|l|}{ Over-identification Test: } \\
\hline Sargan & & & $\begin{array}{c}2.3469 \\
{[0.1255]}\end{array}$ & \\
\hline Basmann & & & $\begin{array}{c}2.3428 \\
{[0.1259]}\end{array}$ & \\
\hline Hansen's J Test & & & & $\begin{array}{l}2.72844 \\
{[0.1255]}\end{array}$ \\
\hline $\begin{array}{l}\text { Test of Endogeneity: } \\
\text { Durbin }\end{array}$ & & & $\begin{array}{c}8.74437^{* * *} \\
{[0.0002]}\end{array}$ & \\
\hline Wald test of exogeneity & & $\begin{array}{c}18.36^{* * *} \\
{[0.0001]}\end{array}$ & & \\
\hline Wu-Hausman & & & $\begin{array}{c}10.540 * * * \\
{[0.0000]}\end{array}$ & \\
\hline GMM C statistic & & & & $\begin{array}{c}18.8408^{* * *} \\
{[0.0001]}\end{array}$ \\
\hline
\end{tabular}

Robust standard errors in parentheses; ${ }^{* * *} p<0.01,{ }^{* *} p<0.05,{ }^{*} p<0.1$; Probability values in [] 
Table 7: Robustness Check using Binomial Logit GEE Models on Tax Compliance in SSA

\begin{tabular}{|c|c|c|c|}
\hline Sales Indices & $\begin{array}{l}\text { Model } 1 \\
\text { Baseline }\end{array}$ & $\begin{array}{c}\text { Model } 2 \\
\text { With Bribery }\end{array}$ & $\begin{array}{c}\text { Model } 3 \\
\text { With Controlled }\end{array}$ \\
\hline Sales bribe & & $\begin{array}{c}-0.00770 * * * \\
(0.00242)\end{array}$ & $\begin{array}{c}-0.0173^{* * *} \\
(0.00443)\end{array}$ \\
\hline Tax bribe & & $\begin{array}{l}-0.0708 \\
(0.0505)\end{array}$ & $\begin{array}{l}-0.117 \\
(0.0783)\end{array}$ \\
\hline Tax rate obstacle & $\begin{array}{c}0.0372^{*} \\
(0.02193)\end{array}$ & $\begin{array}{l}0.00651 \\
(0.0148)\end{array}$ & $\begin{array}{l}0.0375^{*} \\
(0.0220)\end{array}$ \\
\hline Tax Regulation obstacle & $\begin{array}{l}-0.0151 \\
(0.02400)\end{array}$ & $\begin{array}{l}0.00842 \\
(0.0159)\end{array}$ & $\begin{array}{c}-0.00377 \\
(0.0243)\end{array}$ \\
\hline Tax inspection freq. & $\begin{array}{c}-0.0029884 \\
(0.00512)\end{array}$ & $\begin{array}{c}-0.000940 \\
(0.00308)\end{array}$ & $\begin{array}{c}-0.000391 \\
(0.00522)\end{array}$ \\
\hline Biz licence obstacle & $\begin{array}{c}-0.0572^{* * *} \\
(0.02151)\end{array}$ & $\begin{array}{c}-0.0256^{*} \\
(0.0142)\end{array}$ & $\begin{array}{c}-0.0506^{* *} \\
(0.0216)\end{array}$ \\
\hline Electricity from gen & $\begin{array}{l}-0.00108 \\
(0.00191)\end{array}$ & $\begin{array}{c}-0.00285^{* * *} \\
(0.00102)\end{array}$ & $\begin{array}{l}-0.00101 \\
(0.00191)\end{array}$ \\
\hline Uncorrupt judiciary & & & $\begin{array}{c}0.0361 \\
(0.0273)\end{array}$ \\
\hline Lnsales & $\begin{array}{c}0.0116 \\
(0.0110)\end{array}$ & & $\begin{array}{c}0.0140 \\
(0.0110)\end{array}$ \\
\hline Size & $\begin{array}{c}0.0922^{* * *} \\
(0.02410)\end{array}$ & & $\begin{array}{c}0.0833^{* * *} \\
(0.0251)\end{array}$ \\
\hline Age & $\begin{array}{l}-0.00004 \\
(0.00011)\end{array}$ & & $\begin{array}{l}-1.40 \mathrm{e}-05 \\
(0.000106)\end{array}$ \\
\hline Sole proprietorship & $\begin{array}{c}-0.3473^{* * *} \\
(0.06401)\end{array}$ & & $\begin{array}{c}-0.353^{* * *} \\
(0.0641)\end{array}$ \\
\hline Partnership & $\begin{array}{c}0.0312 \\
(0.07651)\end{array}$ & & $\begin{array}{c}0.0225 \\
(0.0767)\end{array}$ \\
\hline Private ownership & $\begin{array}{l}0.00321^{* *} \\
(0.00141)\end{array}$ & & $\begin{array}{c}0.00284^{* *} \\
(0.00141)\end{array}$ \\
\hline Foreign ownership & $\begin{array}{c}0.0027^{*} \\
(0.00154)\end{array}$ & & $\begin{array}{c}0.00219 \\
(0.00155)\end{array}$ \\
\hline Constant & $\begin{array}{c}1.3297^{* * *} \\
(0.3534)\end{array}$ & $\begin{array}{c}0.633^{* * *} \\
(0.114)\end{array}$ & $\begin{array}{c}1.385^{* * *} \\
(0.359)\end{array}$ \\
\hline Year effect & Yes & No & Yes \\
\hline Industrial effect & Yes & No & Yes \\
\hline Country effect & Yes & No & Yes \\
\hline Observations & 15,885 & 15,885 & 15,885 \\
\hline
\end{tabular}

Standard errors in parentheses ${ }^{* * *} p<0.01,{ }^{* *} p<0.05,{ }^{*} p<0.1$

cance of business license obstacle and electricity from generator(s), which implies that the higher the incidence of business obstacle the less the sales percentage to be reported for tax purposes. This has been consistent even in the presence of bribery and corruption in the models. Certainly, the essence of bribing is to boycott a given laid-down procedure and it is feasible that firms establish that the bribery given out may be lower than the proportion of sales not reported for tax purposes. Thus, this makes it comfortable for the firms to conceal their income and other tax bases. This finding is consistent with those of Nur-Tegin (2008), Richter et al. (2009), Joulfaian (2009) and Alm et al. (2016). 
The study established that tax rate and regulation obstacles rather encourage firms to report more sales for tax purposes, perhaps due to harsh penalties associated with evasion, or incentives characterizing compliance in terms of tax holidays and relief packages. It also found that trust-building actions are better than deterring ones in making firms to comply with tax payments as implied by negative significance of business license obstacle. This supports the SSF's proposition that firms comply voluntarily when they believe that states are able to utilize the tax proceeds effectively to provide them with public goods and services that would ease the cost of doing business in the region. This is in line with the findings of Gangl et al. (2014) and Lisi (2014). In addition, the study suggested that firm size is positively and significantly associated with tax compliance. This might be due to the fact that large-scale firms have the resources needed to pay all their taxes and may not be willing to accept embarrassment associated with tax non-compliance. This has rather corroborated the observation made in Table1. Finally, being sole proprietorship negatively influence tax compliance among firms in SSA, compared to shareholding companies. This also confirms that firm's size seriously affects proportion of sales for tax purposes because sole proprietorships usually operate on a small scale. As expected, uncorrupt, impartial and just judiciary system has been found to be critical in controlling corruption in bribery and, encouraging tax compliance among firms in SSA.

\section{Conclusion and Policy Implications}

Since taxation remains instrumental to revenue generation, equitable income distribution, healthy production and consumption of goods and services, and macroeconomic stability; tax revenue relative to GDP is nonetheless modest in the world, especially in the developing economies. Tax non-compliance (in forms of tax avoidance and invasion) is considered to be the major driver of meager tax revenue. This study has been set out to test the validity of extended Slippery Slope Model of tax compliance among firms in SSA. It applied Instrumental Variables (IV) and generalized estimating equations (GEE) models on a constructed World Bank's Enterprise Survey longitudinal dataset to achieve the objective. The study suggests that the perceived power of the tax authorities does not influence firm's tax compliance. This might be linked to the significance of corruption in the form of informal payment. In other words, corruption encourages the culture of tax non-compliance among firms in SSA because defaulting firms bribe tax authorities in order to avoid paying taxes and being punished for that. Interestingly, obstacle in obtaining business license encourages tax non-compliance among firms. This suggests that the perceived trust of tax authorities is very important in encouraging tax compliance among firms in SSA. In addition, the size of the firms has been found to encourage firms to report more proportion of sales for tax purposes in SSA. This has been further corroborated by the negative effect of being sole proprietorship.

The present study should be seen as a breakthrough in the literature in light of its 
contributions. The assessment of the determinants of tax compliance using large sample data from an understudied region of SSA has added new knowledge to our understanding of tax compliance in countries with weak institutions and lack and/or absence of trust from citizens. As expected, the findings are not fully in line with the findings of previous studies, particularly from developed societies. In the mediator analysis, corruption has been found to be an interplay in assessing the assumptions of SSF. Thus, our study buttresses the need for extending the SSF in the analysis of the determinants of tax compliance. Using firm-level data in the analysis of determinants of tax compliance, this study contributes to the ongoing debate that it is unlikely that a single unifying theory of tax compliance can ever be devised, one that incorporates the variations and differences in individuals and firms in responding to tax compliance. Perhaps our study acknowledges the view of Alm (2018) that a theory of taxpayer compliance must really consist of a full house of theories, each explaining the behavior of different individuals and firms in different locations.

The political implication of this study is that measures against firms' tax non-compliance should focus more on gaining trust of taxpayers by fighting corruption as well as effective and efficient utilization of tax revenue in the provision of public goods and services. The policy should also pay more attention to firms' scale of operation, ensure fair tax rates and ease the cost of doing business in SSA.

The publication was co-financed by the "Excellent Science" program of the Minister of Science and Higher Education (currently Minister of Education and Science).

Dofinansowano z programu "Doskonała nauka" Ministra Nauki i Szkolnictwa Wyższego (obecnie Ministra Edukacji i Nauki).

\section{References}

Alabede, J. O., Ariffin, Z. Z., and Idris, K. M. (2011). Determinants of tax compliance behaviour: A proposed model for Nigeria. International Research Journal of Finance and Economics, 78(1):121-136.

Allingham, M. G. and Sandmo, A. (1972). Income tax evasion: a theoretical analysis. Journal of Public Economics, 1(3-4):323-338.

Alm, J. (2018). What Motivates Tax Compliance? Journal of Economic Surveys, $33(2): 353-388$. 
Alm, J., Blackwell, C., and McKee, M. (2004). Audit Selection and Firm Compliance with a Broad-based Sales Tax. National Tax Journal, 57(2):209-227.

Alm, J., Martinez-Vazquez, J., and McClellan, C. (2016). Corruption and Firm Tax Evasion. Journal of Economic Behavior \& Organization, 124(C):146-163.

Almunia, M. and Lopez-Rodriguez, D. (2018). Under the Radar: The Effects of Monitoring Firms on Tax Compliance. American Economic Journal: Economic Policy, 10(1):1-38.

Alon, A. and Hageman, A. M. (2013). The Impact of Corruption on Firm Tax Compliance in Transition Economies: Whom Do You Trust? Journal of Business Ethics, 116(3):479-494.

Amoh, J. K. and Ali-Nakyea, A. (2019). Does corruption cause tax evasion? Evidence from an emerging economy. Journal of Money Laundering Control, 22(2):217-232.

Antinyan, A., Corazzini, L., and Pavesi, F. (2020). Does trust in the government matter for whistleblowing on tax evaders? Survey and experimental evidence. Journal of Economic Behavior \& Organization, 171:77-95.

Ayuba, A., Saad, N., and Ariffin, Z. Z. (2018). Testing the Assumptions of Slippery Slope Framework on Tax Compliance: Evidence from Nigerian SMEs. DLSU Business 86 Economics Review, 27(2):166-178.

Babatunde, O. A., Ibukun, A. O., and Oyeyemi, O. G. (2017). Taxation revenue and economic growth in Africa. Journal of Accounting and Taxation, 9(2):11-22.

Baum, A. and Gupta, S. (2017). Corruption, Taxes and Compliance. IMF Working Papers, 15(2):190-216.

Bertinelli, L., Bourgain, A., and Léon, F. (2020). Corruption and tax compliance: evidence from small retailers in Bamako, Mali. Applied Economics Letters, 27(5):366-370.

Cai, H. and Liu, Q. (2009). Competition and Corporate Tax Avoidance: Evidence from Chinese Industrial Firms. The Economic Journal, 119(537):764-795.

Cameron, A. C. and Trivedi, P. K. (2005). Microeconometrics: Methods and Applications. Cambridge: Cambridge University Press.

Cobham, A. and Janský, P. (2017). Global distribution of revenue loss from tax avoidance: Re-estimation and country results. Working Paper 2017/55, United Nations University World Institute for Development Economic Research WIDER.

Crivelli, E., de Mooij, R., and Keen, M. (2016). Base Erosion, Profit Shifting and Developing Countries. FinanzArchiv: Public Finance Analysis, 72(3):268-301. 
Damayanti, T. and Martono, S. (2018). Taxpayer Compliance, Trust, and Power. Jurnal Keuangan dan Perbankan, 22(2):231-239.

Djankov, S., Ganser, T., McLiesh, C., Ramalho, R., and Shleifer, A. (2010). The Effect of Corporate Taxes on Investment and Entrepreneurship. American Economic Journal: Macroeconomics, 2(3):31-64.

Engida, T. G. and Baisa, G. A. (2014). Factors Influencing taxpayers' compliance with the tax system: An empirical study in Mekelle City, Ethiopia. eJournal of Tax Research, 12:433-452.

Federal Inland Revenue Service (2018). Tax Statistics/Reports: Annual Summary of Collection from Year 2000. 11 September 2018. https://www.firs.gov.ng/ tax-statistics.html.

Gangl, K., Hofmann, E., Hartl, B., and Berkics, M. (2020). The impact of powerful authorities and trustful taxpayers: evidence for the extended slippery slope framework from Austria, Finland, and Hungary. Policy Studies, 41(1):98-111.

Gangl, K., Torgler, B., Kirchler, E., and Hofmann, E. (2014). Effects of supervision on tax compliance: Evidence from a field experiment in Austria. Economics Letters, 123(3):378-382.

Gauthier, B. and Reinikka, R. (2006). Shifting Tax Burdens through Exemptions and Evasion - An Empirical Investigation of Uganda. Journal of African Economies, 15(3):373398.

Gberegbe, F. B. and Umoren, A. O. (2017). The Perception of Tax Fairness and Personal Income Tax Compliance of Smes in Rivers State. Journal of Research in Business and Management, 5(2):40-51.

Hibbs, D. A. and Piculescu, V. (2010). Tax Toleration and Tax Compliance: How Government Affects the Propensity of Firms to Enter the Unofficial Economy. American Journal of Political Science, 54(1):18-33.

Jahnke, B. and Weisser, R. A. (2019). How does petty corruption affect tax morale in Sub-Saharan Africa? European Journal of Political Economy, 60:101751.

Joulfaian, D. (2009). Bribes and Business Tax Evasion. The European Journal of Comparative Economics, 6(2):227-244.

Kahneman, D. and Tversky, A. (1979). Prospect Theory: An Analysis of Decision under Risk. Econometrica, 47(2):263-291. 
Kamasa, K., Adu, G., and Oteng-Abayie, E. F. (2019). Tax Compliance in Sub-Saharan Africa: How Important are Non-Pecuniary Factors? African Journal of Economic Review, 7(1):154-175.

Kastlunger, B., Lozza, E., Kirchler, E., and Schabmann, A. (2013). Powerful authorities and trusting citizens: The Slippery Slope Framework and tax compliance in Italy. Journal of Economic Psychology, 34(c):36-45.

Kirchler, E., Hoelzl, E., and Wahl, I. (2008). Enforced versus voluntary tax compliance: The "slippery slope" framework. Journal of Economic Psychology, 29(2):210-225.

Kirchler, E., Kogler, C., and Muehlbacher, S. (2014). Cooperative Tax Compliance: From Deterrence to Deference. Current Directions in Psychological Science, 23(2):87-92.

Kirchler, E., Muehlbacher, S., Hoelzl, E., and Webley, P. (2009). Effort and Aspirations in Tax Evasion: Experimental Evidence. Applied Psychology: An International Review, $58(3): 488-507$.

Kirchler, E. and Wahl, I. (2010). Tax compliance inventory TAX-I: Designing an inventory for surveys of tax compliance. Journal of Economic Psychology, 31(3):331-346.

Kleven, H. J., Kreiner, C. T., and Saez, E. (2016). Why Can Modern Governments Tax So Much? An Agency Model of Firms as Fiscal Intermediaries. Economica, 83(330):219246.

Lee, Y. and Gordon, R. H. (2005). Tax structure and economic growth. Journal of Public Economics, 89(5-6):1027-1043.

Lisi, G. (2014). The interaction between trust and power: Effects on tax compliance and macroeconomic implications. Journal of Behavioral and Experimental Economics, $53(\mathrm{C}): 24-33$.

Lisi, G. (2019). Slippery slope framework, tax morale and tax compliance: a theoretical integration and an empirical assessment. Discussion Papers in Economic Behaviour, $2: 19$.

Mardhiah, M., Miranti, R., and Tanton, R. (2019). The Slippery Slope Framework: Extending the Analysis by Investigating Factors Affecting Trust and Power. CESifo Working Paper Series 7494, CESifo Group Munich.

Martinez-Vazquez, J. and Sanz-Arcega, E. (2020). Can Pre-Populated Tax Returns Enhance Tax Compliance? The Effects of the Spanish Renta Web Initiative from a Sociology of Taxation Perspective. International Center for Public Policy Working Paper Series, at AYSPS, GSU paper2009, International Center for Public Policy, Andrew Young School of Policy Studies, Georgia State University. 
McCullagh, P. and Nelder, J. A. (1989). Generalized Linear Models. London: Chapman and Hall/CRC, 2 edition.

Mendoza, E. G., Razin, A., and Tesar, L. L. (1994). Effective Tax Rates in Macroeconomics: Cross-Country Estimates of Tax Rates on Factor Incomes and Consumption. Journal of Monetary Economics, 34(3):297-323.

Muller, A. and Kolk, A. (2015). Responsible Tax as Corporate Social Responsibility: The Case of Multinational Enterprises and Effective Tax in India. Business 8 Society, $54(4): 435-463$.

Murphy, R. (2019). Tax and modern monetary theory. Real-World Economics Review, 89(89):138-147.

Naibei, K. and Siringi, E. (2011). Impact of Electronic Tax Registers on VAT Compliance: A Study of Private Business Firms. African Research Review, 5(1):73-88.

Nur-Tegin, K. D. (2008). Determinants of Business Tax Compliance. The B.E. Journal of Economic Analysis \& Policy, 8(1):1-28.

Payne, J. E. and Saunoris, J. W. (2020). Corruption and Firm Tax Evasion in Transition Economies: Results from Censored Quantile Instrumental Variables Estimation. Atlantic Economic Journal, 48(2):195-206.

Richter, B. K., Samphantharak, K., and Timmons, J. F. (2009). Lobbying and Taxes. American Journal of Political Science, 53(4):893-909.

Rosid, A., Evans, C., and Tran-Nam, B. (2017). Perceptions of Corruption and Tax Non-Compliance Behaviour: Policy Implications for Developing Countries. Bulletin of Indonesian Economic Studies, 54(1):25-60.

Rosid, A., Evans, C., and Tran-Nam, B. (2019). Perceptions of Corruption and Tax Non-Compliance Behaviour: Policy Implications for Developing Countries. Available at SSRN 3317994.

Sapiei, N. S., Kasipillai, J., and Eze, U. C. (2014). Determinants of tax compliance behaviour of corporate taxpayers in Malaysia. eJournal of Tax Research, 12(2):383409.

Slemrod, J. (2007). Cheating Ourselves: The Economics of Tax Evasion. Journal of Economic Perspectives, 21(1):25-48.

Srinivasan, T. N. (1973). Tax evasion: A model. Journal of Public Economics, 2(4):339346. 
Studenmund, A. H. (2014). Using Econometrics: A Practical Guide. Essex: Pearson Education Limited, 6 edition.

Ufere, N., Gaskin, J., Perelli, S., Somers, A., and Boland Jr, R. (2020). Why is bribery pervasive among firms in sub-Saharan African countries? Multi-industry empirical evidence of organizational isomorphism. Journal of Business Research, 108:92-104.

Varotsis, N. and Katerelos, I. (2020). Tax behaviour relating to the review of a revised regional tax policy: a study in Greece. Journal of Economic Structures, 9(7):1-16.

World Bank (2018a). Business Enterprise Surveys. Washington DC: The World Bank Group. https://www .enterprisesurveys .org/.

World Bank (2018b). World Development Indicators. Washington DC: The World Bank Group.

Yee, C. P., Moorthy, K., and Soon, W. C. K. (2017). Taxpayers' perceptions on tax evasion behaviour: an empirical study in Malaysia. International Journal of Law and Management, 59(3):413-429.

Yitzhaki, S. (1974). A Note on Income Tax Evasion: A Theoretical Analysis. Journal of Public Economics, 3(2):201-202.

Zambrano, G. J. (2005). Modified maximum likelihood estimation of tobit models with fixed effects: Theory and an application to earnings equations. Investigaciones Económicas, 29(3):575-607.

Zeng, K., Li, S., and Li, Q. (2013). The Impact of Economic Growth and Tax Reform on Tax Revenue and Structure: Evidence from China Experience. Modern Economy, $4(12): 839-851$. 